\title{
Structural and Functional Studies of Ligandin,
}

\section{a Major Renal Organic Anion-Binding Protein}

\author{
R. Kirsch, G. Fletschner, K. Kamisaka, and I. M. Arias \\ From the Department of Medicine and the Liver Research Center, \\ Albert Einstein College of Medicine, Bronx, New York 10461
}

\begin{abstract}
A B S T R A C T Sephadex gel filtration of the $100,000 \mathrm{~g}$ supernate of homogenates of rat kidney revealed binding of various organic anions (penicillin, Bromsulphalein [BSP], bilirubin, phenolsulfonphthalein [PSP], phlorizin, glutathione [GSH], p-amino hippurate (PAH), probenecid, conjugated bilirubin, and BSP-GSH) to a nonalbumin-containing protein fraction $(Y)$, which precipitated on addition of monospecific anti-rat liver ligandin ( $Y$ protein)-IgG, but not control IgG. Quantitatively similar organic anion binding was observed in vivo after injection of BSP, BSP-GSH, phlorizin, probenecid, conjugated bilirubin, $\mathrm{PAH}$, or penicillin. The binding protein was purified to apparent homogeneity and is a basic protein (pI 8.9) of 44,000 daltons with two apparently identical subunits of 22,000 daltons. Monospecific antibody was produced against the renal protein. The results of binding studies in vivo and in vitro and physicochemical, immunologic, structural, and binding site investigations indicate that the renal protein is identical to hepatic ligandin. Immunofluorescent studies utilizing anti-ligandin IgG previously localized ligandin in the kidney to all proximal tubular cells.

By quantitative radial immunodiffusion, the concentration of renal ligandin was $31.2 \pm 2.2 \mu \mathrm{g} / \mathrm{mg}$ supernatant protein and was increased $160 \%$ above basal values by pretreatment of rats with tetrachloro-dibenzop-dioxin. Pretreatment with phenobarbital, DDT, or pregnene-16 $\alpha$-carbonitrile did not increase renal ligandin concentration but doubled hepatic ligandin concentration. Circular dichroism studies of renal ligandin revealed percent helical structure similar to hepatic
\end{abstract}

Dr. Kirsch was the recipient of the U. S. Public Health Service International Research Fellowship (TW 1851). His present address is: University of Cape Town Medical School, Department of Medicine, Observatory Cape, South Africa. Dr. Fleischner was the recipient of U. S. Public Health Service Clinical Investigators Award (AM 70228).

Received for publication 3 June 1974 and in revised form 28 December 1974. ligandin and primary association constants were derived for $\mathrm{BSP}\left(10^{\circ} \mathrm{M}^{-1}\right)$ and $\mathrm{PAH}$, probenecid, and penicillin $\left(10^{8} \mathrm{M}^{-1}\right)$.

Administration of BSP or probenecid simultaneously with $\left[\mathrm{C}^{14}\right]$ penicillin resulted in increased plasma retention and reduced kidney and urinary bladder content of $\left[{ }^{14} \mathrm{C}\right]$ penicillin and a correlation coefficient of -0.8 between total kidney/plasma radioactivity and percent of protein-bound radioactivity bound to ligandin in the kidney.

These studies indicate that renal and hepatic ligandin are identical. Their response to drugs and chemicals varies. Competitive binding between several organic anions for ligandin correlated with their renal uptake from plasma, which suggests that ligandin may function in the proximal tubular cell as a component of the renal organic anion transport system.

\section{INTRODUCTION}

Ligandin ( $Y$ protein $)^{1}$ is a basic protein isolated from supernates of human and rat liver homogenates that binds various organic anions in vivo and in vitro, and is considered to be an important determinant in their transfer from plasma into parenchymal liver cells (1-6). Immunodiffusion analysis with a monospecific antiserum against rat liver ligandin demonstrated an immunologically similar protein in kidney (6), which, on immunofluorescent analysis, is restricted to the proximal tubular cells (7).

We have now studied physicochemical and immunological characteristics of this renal tubular protein in rat kidney, its ability to bind organic anions, and its possible role in proximal tubular transport of organic anions.

\footnotetext{
${ }^{1}$ Abbreviations used in this paper: BSP, Bromsulphalein; $\mathrm{PAH}, p$-aminohippurate; $\mathrm{PCN}$, pregnenolone-16 $\alpha$-carbonitrile; PSP, phenolsulfonphthalein; SDS, sodium dodecyl sulfate; TCDD, tetrachloro-dibenzo-p-dioxan; $\mathrm{Y}$ protein, ligandin.
} 


\section{METHODS}

Adult male Sprague-Dawley rats weighing 250-350 g were anesthetized with ether. The kidneys were removed, immediately washed in ice-cold isotonic saline, weighed, and perfused through hilar vessels with $2.5 \mathrm{ml}$ isotonic saline at $4^{\circ} \mathrm{C}$ to remove as much blood as possible. A $25 \%$ homogenate was prepared in $0.25 \mathrm{M}$ sucrose $-0.01 \mathrm{M}$ phosphate buffer, $\mathrm{pH}$ 7.4, with a Teflon-glass, motor-driven homogenizer (Arthur H. Thomas Co., Philadelphia, Pa.). Homogenates were centrifuged at $2{ }^{\circ} \mathrm{C}$ in a Beckman Spinco model L ultracentrifuge (Beckman Instruments Inc., Spinco Div., Palo Alto, Calif.) at $100,000 \mathrm{~g}$ for $120 \mathrm{~min}$. Supernate fractions were removed with Pasteur pipettes without disturbing the precipitate or surface lipid layer. Unless immediately used, supernates were stored at $-20^{\circ} \mathrm{C}$ for a period not exceeding 1 mo.

Binding studies in vitro were performed by adding 1-2 $\mu \mathrm{mol}$ of the organic anion to be tested to $5 \mathrm{ml}$ of supernatant fraction from a $25 \%$ kidney homogenate and chromatographing the mixture at $4^{\circ} \mathrm{C}$ in a standardized manner on a Sephadex G-100 column $(100 \times 3 \mathrm{~cm})$, equilibrated with $0.01 \mathrm{M}$ phosphate buffer, $\mathrm{pH}$ 7.4. The average protein concentration of the supernatant fraction tested was $17 \mathrm{mg} / \mathrm{ml}$. Elution was performed with the same buffer and a pumpdriven upward flow system, which permitted accurately timed collections of constant volume $(3 \mathrm{ml} /$ tube). The flow rate was $15 \mathrm{ml} / \mathrm{h}$. The protein concentration of eluted fractions was estimated at $280 \mathrm{~nm}$ with a Beckman D/U spectrophotometer (Beckman Instruments, Fullerton, Calif.).

The following organic anions were studied: sodium sulfobromophthalein (BSP) (Hynson, Westcott \& Dunning, Inc., Baltimore, Md.), recrystallized bilirubin (Sigma Chemical Co., St. Louis, Mo.), phenolsulfonphthalein (PSP) (Torigian Labs., Inc., Queens Village, N. Y.), $\left[{ }^{14} \mathrm{C}\right]$ benzylpenicillin (potassium salt) (Amersham/Searle Corp., Arlington Heights, Ill.), [G- $\left.{ }^{3} \mathrm{H}\right]$ phlorizin and $\left[{ }^{3} \mathrm{H}\right]-$ glutathione (GSH) (New England Nuclear, Boston, Mass.), [glycine- $\left.2{ }^{3} \mathrm{H}\right] p$-aminohippuric acid $(\mathrm{PAH})$ (New England Nuclear), $\left[\right.$ ring $\left.-{ }^{14} \mathrm{C}\right]$ probenecid (Merck and Co.,Inc., Rahway, N. J.). Conjugated bilirubin was prepared from bile duct-cannulated rats (8), and BSP-GSH was prepared synthetically (9). The purity of each organic anion studied was established by thin-layer chromatography in at least two solvent systems with subsequent serial elution and either colorimetric or radio-isotopic localization. Purity of conjugated bilirubin was $78 \%$, whereas all other organic anions studied were $98-100 \%$ pure. Organic anions were determined spectrophotometrically: BSP $580 \mathrm{~nm}$ after alkalinization, heme $410 \mathrm{~nm}$, bilirubin $460 \mathrm{~nm}$, and PSP 560 $\mathrm{nm}$. When labeled organic anions were used, samples were counted in an Intertechnique liquid scintillation spectrophotometer (model SL40, Intertechnique, Dover, N. J.). Aquasol (New England Nuclear) was the scintillation fluid and all samples were corrected for quenching with an external standard. Efficiency of counting was $60-85 \%$ for ${ }^{14} \mathrm{C}$ and $20-35 \%$ for ${ }^{3} \mathrm{H}$. Radioactivity was expressed in disintegrations per minute. Organic anion binding to various proteins was quantitated by integration of the area under each peak. When performed in a standardized manner (1), this procedure provides reproducible relative binding of organic anions to the various supernatant protein fractions. To exclude minor variations in amounts of protein or organic anions applied to the column (1), results were expressed as a fraction of the total protein-bound organic anion eluted from the column up to 2.5 times the void volume.
To identify specific proteins in the various organic anionbinding fractions obtained by G-100 chromatography, immunodiffusion analysis against monospecific antisera prepared against purified rat albumin and liver ligandin was performed with each fraction (6).

To determine whether organic anion binding in the $\mathrm{Y}$ fraction (1) obtained by gel filtration of the kidney supernate was due to a protein that reacts immunologically with anti-liver ligandin, the following experiment was performed. $5-\mathrm{ml}$ samples of $\mathrm{Y}$ fraction obtained by Sephadex G-100 chromatography of the supernate of $25 \%$ kidney homogenate were added to tubes containing $5 \mathrm{ml}$ of isotonic saline, monospecific anti-rat liver ligandin IgG or nonspecific rabbit IgG as previously described (6). The mixtures were separately stirred at room temperature for $1 \mathrm{~h}$ and at $4^{\circ} \mathrm{C}$ for $48 \mathrm{~h}$ after which they were centrifuged at $18,000 \mathrm{~g}$ for $30 \mathrm{~min}$ and any precipitates were separated from the supernatant fractions. $5 \mathrm{mg}$ BSP was added to each of the three supernatant $\mathrm{Y}$ fractions; the mixtures were rechromatographed on a G-100 Sephadex column, and BSP binding was determined as described.

Competitive binding of various organic anions to renal proteins was studied in vivo. Male Sprague Dawley rats, weighing 250-300 g, given rat breeder chow and water ad libitum, were anesthetized with intraperitoneal barbiturate. Temperature was continually monitored by rectal thermometer and, where necessary, artificially maintained at $37-38^{\circ} \mathrm{C}$ by an incandescent lamp. The following organic anions were injected intravenously: $\left[{ }^{3} \mathrm{H}\right] \mathrm{PAH}\left(10^{7} \mathrm{dpm}\right),\left[{ }^{14} \mathrm{C}\right]$ benzyl penicillin $\left(10^{7} \mathrm{dpm}\right), \mathrm{BSP}(25 \mathrm{mg})$, and probenecid $(50$ $\mathrm{mg}$ ). Injection volume was adjusted to $1 \mathrm{ml}$ by addition of isotonic saline. All injections were performed manually over a period of $1 \mathrm{~min}$ with a tuberculin syringe. Precisely 5 min after completion of injection, blood was obtained by cardiac puncture and the kidneys were promptly removed, placed in iced normal saline, and perfused. $5 \mathrm{~min}$ was chosen to allow one circulation of the entire blood volume through the kidneys (10). Kidney homogenates always contained small amounts of blood and presumably tubular urine, which were not completely removed by perfusion, although radioactivity in the perfusate was less than $100 \mathrm{dpm} / 0.2 \mathrm{ml}$ aliquot. After kidney homogenization, supernates were prepared and chromatographed as described. Additional studies were performed with heme-containing supernates of $25 \%$ homogenates of unperfused kidneys from Sprague-Dawley rats and bilirubin-containing supernates of kidneys from homozygous Gunn rats.

To study competition between penicillin, probenecid, and BSP for binding to renal proteins, the urethra was clamped. $\left[{ }^{14} \mathrm{C}\right]$ penicillin $(10 \mathrm{dpm})$ was diluted with $10 \mathrm{mg}$ of nonradioactive benzyl penicillin (potassium salt) and simultaneously injected with isotonic saline, nonradioactive probenecid (50 $\mathrm{mg})$ and BSP $(25 \mathrm{mg})$. Immediately after ligation of the renal pedicles and removal of the kidneys, the urinary bladder was emptied with a microsyringe (Hamilton Co., Reno, Nev.) after injection into the bladder of $0.2-0.5 \mathrm{ml}$ of isotonic saline. Total volume of fluid aspirated was recorded, 10-20 $\mu 1$ of bladder content was used for counting of radioactivity, and total bladder content of radioactive penicillin was calculated. The kidneys and liver were weighed and a $50 \%$ homogenate was prepared in isotonic saline at $4^{\circ} \mathrm{C}$. The total volume of homogenate was measured and $0.1-0.2 \mathrm{ml}$ samples were used for counting of radioactivity. Total plasma radioactivity was calculated from the product of plasma radioactivity and plasma volume. The latter was derived from weight in kilograms $\times 40.4$ 
$\mathrm{ml}$ (11). Renal radioactivity was determined by counting $0.1 \mathrm{ml}$ of homogenate and calculating total renal radioactivity. Radioactivity of supernatant fluid and elution fractions from G-100 Sephadex chromatography was similarly determined. Radioactivity in total plasma, urinary bladder, and kidney and liver homogenates was expressed as a percentage of the dose injected and as the radioactivity ratio in total kidney/total plasma. The relative amount of penicillin radioactivity bound to various proteins was also expressed as a percentage of total protein-bound penicillin radioactivity.

The same procedures were followed in experiments in which $\left[{ }^{14} \mathrm{C}\right]$ penicillin $\left(10^{7} \mathrm{dpm}\right)$ was injected into four rats pretreated i.p. with DDT, $25 \mathrm{mg}$ in corn oil daily for 14 days, or tetrachloro-dibenzo-p-dioxan (TCDD) $(10 \mu \mathrm{g} / \mathrm{kg}$ in p-dioxane $(0.3 \mathrm{ml} / \mathrm{kg})$ and corn oil (total volume: 2 $\mathrm{ml} / \mathrm{kg}$ ) given as a single injection 7 days before study. Control rats for their respective studies received either daily i.p. injections of corn oil for 14 days or a single intraperitoneal injection of $p$-dioxane-corn oil 7 days before study.

A renal organic anion binding protein was purified by the technique previously used to purify hepatic ligandin (7). All procedures were performed at $4^{\circ} \mathrm{C}$. A $100,000 \mathrm{~g}$ supernate was prepared from a $25 \%$ homogenate of $100 \mathrm{~g}$ kidney obtained from 50 rats. The supernate was concentrated to $50 \mathrm{ml}$ by ultrafiltration and dialyzed for $16 \mathrm{~h}$ against $0.01 \mathrm{M}$ Tris buffer, $\mathrm{pH}$ 8.8. Dialyzed supernate was chromatographed on triethylamino ethyl (TEAE) $(100 \times 3$ $\mathrm{cm}$ column) after equilibration with $0.01 \mathrm{M}$ Tris buffer, $\mathrm{pH}$ 8.8. Elution flow was by gravity at $20-30 \mathrm{ml} / \mathrm{h}$ and samples of $3 \mathrm{ml}$ were collected. Protein content was estimated spectrophotometrically on all samples. Aliquots from each protein peak were tested by immunodiffusion against anti-rat liver ligandin IgG (12). Fractions yielding positive results on immunodiffusion were combined and concentrated to $5-10 \mathrm{ml}$ by ultrafiltration. After dialysis for $16 \mathrm{~h}$ against $0.01 \mathrm{M}$ phosphate buffer, $\mathrm{pH} 7.4,5 \mathrm{mg}$ BSP was added to allow identification of binding proteins, and the mixture was chromatographed on a $100 \times 3 \mathrm{~cm}$ Sephadex G-100 column equilibrated with $0.01 \mathrm{M}$ phosphate buffer, $\mathrm{pH} 7.4$. Elution was performed with the same buffer and a pumpdriven, upward flow system. Flow was $15-25 \mathrm{ml} / \mathrm{h}$ and samples of $3 \mathrm{ml}$ were collected. Protein and BSP concentrations in each fraction were determined spectrophotometrically. Each aliquot was tested by immunodiffusion as described. Fractions from the immunoreactive peak were combined, concentrated to $3-5 \mathrm{ml}$, and dialyzed for $16 \mathrm{~h}$ against $0.01 \mathrm{M}$ Tris buffer, $\mathrm{pH}$ 8.8. The concentrate was chromatographed on a $50 \times 1.5 \mathrm{~cm}$ QAE-Sephadex column equilibrated with $0.01 \mathrm{M}$ Tris buffer, $\mathrm{pH} 8.8$, by gravity flow. Flow was $20-30 \mathrm{ml} / \mathrm{h}$ and aliquots of $3 \mathrm{ml}$ were collected. A single protein peak was eluted, concentrated by ultrafiltration, tested for BSP binding, and stored in buffer in sterile containers. Purity of the organic anion binding protein was determined by isoelectric focusing in $6 \%$ polyacrylamide gel (13) and electrophoresis in $0.1 \%$ sodium dodecyl sulfate (SDS) polyacrylamide gel with and without $\beta$-mercaptoethanol (14). Molecular weight was estimated by comparative analysis after simultaneous electrophoresis of appropriate standards. After hydrolysis of $100 \mu \mathrm{g}$ of purified protein in $6 \mathrm{~N} \mathrm{HCl}$ for $16 \mathrm{~h}$ at $110^{\circ} \mathrm{C}$, amino acid analysis was determined on the hydrolysate with a Beckman model $120 \mathrm{C}$ amino acid analyzer (Beckman Instruments, Inc., Fullerton, Calif.). Comparative isoelectric focusing, gel elec- trophoresis, and amino acid analysis were performed with liver ligandin purified identically (7).

6-mo-old male New Zealand rabbits were used for antisera production. Preimmunization sera showed no precipitation reactions on immunodiffusion against renal supernate, purified renal protein, or hepatic ligandin. Renal protein $(50 \mu \mathrm{g})$ was dissolved in $1.0 \mathrm{ml}$ phosphate-buffered saline, $\mathrm{pH} 7.4$, and added to $1.5 \mathrm{ml}$ complete Freund's adjuvant (Difco Laboratories, Detroit, Mich.) containing $10 \mathrm{mg}$ of mycobacterium. The mixture was homogenized for $2.5 \mathrm{~min}$ at top speed in a Sorvall (Sorvall-Dupont Instruments, Sorvall Operations, Newtown, Conn.) omni-homogenizer (micro attachment) (6). The emulsion was injected in $0.1 \mathrm{ml}$ amounts at multiple sites into the foot pads and back of the rabbits. Additional multiple intracutaneous injections of $100 \mu \mathrm{g}$ renal protein and incomplete Freund's adjuvant were performed 3 wk later. When an antibody was produced, as evidenced by a precipitation reaction with a $1: 8$ dilution of rabbit serum and renal protein $(100 \mu \mathrm{g} / \mathrm{ml})$, the animals were bled, blood was allowed to clot at room temperature for $1 \mathrm{~h}$ and then placed at $4^{\circ} \mathrm{C}$ for $24 \mathrm{~h}$, after which serum was removed and centrifuged in a Sorvall centrifuge at $4,000 \mathrm{~g}$ for $30 \mathrm{~min}$ at $4^{\circ} \mathrm{C}$.

The specificity of the antibody was tested by immunodiffusion (12) and immunoelectrophoresis (15) against 1:8 dilutions of rat liver, kidney, and small intestinal mucosal supernates of $25 \%$ homogenates as well as serum, hepatic ligandin, and renal organic binding protein.

Immunologic identity between renal organic anion-binding protein and hepatic ligandin was also studied. Anti-liver ligandin IgG and anti-kidney organic anion-binding protein serum were tested against supernates of rat liver and kidney before and after absorption by each antibody preparation. 100 $\mu l$ of liver and renal supernates were added separately to tubes containing either $800 \mu \mathrm{l}$ of antiserum against renal organic anion-binding protein, anti-liver ligandin IgG, or saline. After $48 \mathrm{~h}$ incubation at $4^{\circ} \mathrm{C}$, the tubes were centrifuged at $18,000 \mathrm{~g}$ for $30 \mathrm{~min}$. Supernatant fluid was removed and tested by immunodiffusion against renal organic anion-binding protein anti-serum or anti-hepatic ligandin IgG.

Immunoquantitation of liver ligandin and renal organic anion-binding protein was performed by radial immunodiffusion (16). With a microsyringe (Hamilton Co.), $8 \mu \mathrm{l}$ of $1: 8$ dilutions of kidney or liver supernates of $25 \%$ homogenates was placed in each well. Each assay was performed in duplicate and each plate contained three standard dilutions of purified protein ranging from 75 to $400 \mu \mathrm{g} / \mathrm{ml}$. Plates were kept at room temperature in a moisture chamber for $48 \mathrm{~h}$ and photographed at a constant magnification, and precipitation rings were carefully cut and weighed. Results were expressed as micrograms ligandin per milligram tissue supernatant protein (6). Protein was quantitated with twicecrystalized bovine serum albumin as a standard (17).

Circular dichroism was utilized to study secondary structure of purified renal organic anion-binding protein and ligandin-protein interaction with a Cary Model 60 recording spectropolarimeter (Cary Instruments, Monrovia, Calif.) (18-20). Renal organic anion-binding protein and hepatic ligandin were studied separately and in combination with various organic anions to compare structure, binding sites, and binding affinities. Absorbance was kept below 2 by cell path lengths of $10 \mathrm{~mm}$. Slit width was programed for a band width of $15 \AA$, the time constant was 3 and the scale setting was 0.01 . The spectral range studied was between 600 and $270 \mathrm{~nm}$. The $\alpha$ helical component of ligandin was determined by a computer with standards as described by 


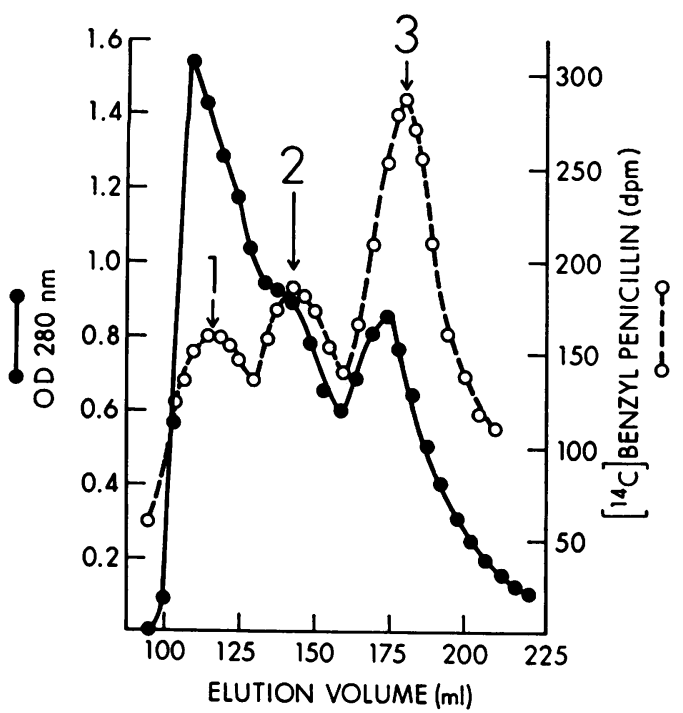

FIgure 1 Binding of $\left[{ }^{14} \mathrm{C}\right]$ penicillin to protein fractions obtained by chromatography on Sephadex G-100 of 100,000 $g$ supernate of rat kidney homogenate. $\left[{ }^{14} \mathrm{C}\right]$ penicillin (1 $\mu \mathrm{Ci}$ ) was added to $5 \mathrm{ml}$ of $100,000 \mathrm{~g}$ supernatant fraction from a $25 \%$ kidney homogenate before chromatography.

Greenfield and Fasman (21) and Chen, Yang, and Martinez (22). Bilirubin solutions were prepared daily at concentrations of $10^{-8} \mathrm{M}$ by addition of $20 \mathrm{mM}$ aqueous $\mathrm{NaOH}$. Solutions were protected from light and stored at $3^{\circ} \mathrm{C}$ in the dark. BSP, penicillin, PAH, and probenecid were prepared at concentrations of $10^{-8} \mathrm{M}$ in distilled water. The concentration of renal binding protein and hepatic ligandin

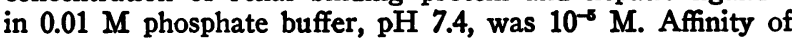
each ligand for the protein was estimated as previously described (19).

Several attempts were made to modify hepatic ligandin and renal organic anion binding protein concentrations. These included daily subcutaneous administration for 14 days of phenobarbital, $8 \mathrm{mg} / 100 \mathrm{~g}$; daily i.p. administration of DDT for 14 days, $25 \mathrm{mg}$ in corn oil; daily i.p. administration of pregnenolone-16a-carbonitrile (PCN), $10 \mu \mathrm{g} / \mathrm{kg}$ or single i.p. injection of TCDD $(10 \mu \mathrm{g} / \mathrm{kg})$ in $p$-dioxane $(0.3 \mathrm{ml} / \mathrm{kg}$ ) and corn oil (total volume, $2 \mathrm{ml} / \mathrm{kg}$ ) given by microsyringe 7 days before study. Littermates were injected with equal volumes of saline, corn oil or corn oil-dioxane where appropriate and served as controls. Hepatic ligandin and renal organic anion-binding protein were quantitated by radial immunodiffusion and results were expressed as micrograms ligandin per milligram protein. The concentration of renal organic anion-binding protein was also estimated in newborn Sprague-Dawley rats killed by decapitation within $6 \mathrm{~h}$ of birth. Supernates of 25\% homogenates were prepared for pooled kidneys of each litter.

Statistical analysis was by Student's $t$ test.

\section{RESULTS}

Fig. 1 illustrates the binding of penicillin to protein fractions obtained by Sephadex G-100 gel filtration of supernate of rat kidney homogenates to which $\left[{ }^{2 \prime} \mathrm{C}\right]-$ benzyl penicillin was added. Three peaks of penicillin binding to protein were obtained; one was in the void volume; the second occurred at 1.4 times the void volume, and the third, the major organic anion-binding peak, occurred at 1.8 times the void volume. By immunodiffusion, albumin was restricted to the second binding peak, and anti-rat albumin selectively precipitated $95 \%$ of radioactivity bound in this fraction. Reactivity to anti-hepatic ligandin was restricted to the third binding peak.

Repeated Sephadex chromatography of supernates to which penicillin was added in vitro revealed a constant pattern of binding. Validity of the gel filtration technique for comparative assessment of organic anion binding to supernatant protein has been established (1, 4). The reproducibility of the technique is further indicated by results obtained from six separate experiments with renal supernate and $\left[{ }^{14} \mathrm{C}\right]$ benzyl penicillin. In these experiments, the void volume peak accounted for $14.2 \pm 1.7 \%$ (mean $\pm \mathrm{SEM}$ ) of total protein-bound radioactivity. The albumin-containing peak accounted for $31.5 \pm 1.8 \%$ and the peak containing protein that reacts with anti-liver ligandin IgG accounted for 53.0 $1.4 \%$ of total bound radioactivity. The following other organic anions were bound to the same three peaks and similar reproduceability was demonstrated: BSP, BSP-GSH, bilirubin, conjugated bilirubin, PAH, PSP, phlorizin, heme, and probenecid. From 10 to $48 \%$ of each organic anion added in vitro was bound to renal supernatant protein, and $53-90 \%$ of each organic anion bound to renal supernate was bound to the third protein peak (Table I). When kidneys containing blood were homogenized and similarly chromatographed, heme $(410 \mathrm{~nm})$ was almost entirely restricted to the third organic anion-binding peak. When supernatant from $25 \%$ homogenates of homozygous Gunn rat kid-

TABLE I

Distribution of Various Organic Anions after their Addition to Rat Kidney Supernate in vitro before Fractionation on Sephadex G-100

\begin{tabular}{lrrrrr}
\hline & \multicolumn{3}{c}{ Protein peak } & \\
\cline { 2 - 4 } & A & B & C & $\begin{array}{r}\text { Protein-bound } \\
\text { organic anion }\end{array}$ \\
\hline & \multicolumn{3}{c}{ \% of protein-bound } & \% of dose \\
organic & anion & & \\
Penicillin & 14 & 32 & 53 & 10 \\
BSP & 8 & 25 & 66 & 23 \\
BSP-GSH & 10 & 30 & 60 & 15 \\
Bilirubin & 6 & 20 & 74 & 48 \\
Conjugated bilirubin & 10 & 24 & 66 & 14 \\
PAH & 11 & 21 & 68 & 19 \\
Probenecid & 4 & 37 & 59 & 24 \\
Phlorizin & 6 & 32 & 62 & 27 \\
PSP & 8 & 2 & 90 & 35 \\
GSH & 3 & 9 & 88 & 32 \\
\hline
\end{tabular}

See Methods for further details. 
neys was chromatographed, the bilirubin-binding pattern was the same as observed after addition of bilirubin to homogenates of kidney from normal rats.

The contribution of the protein that reacts with antirat ligandin to the major organic anion-binding peak obtained by gel filtration was assessed by incubating the G-100 Y fraction with anti-rat liver ligandin IgG, nonspecific IgG, and isotonic saline (Fig. 2). In tubes to which isotonic saline was added, a dye-binding peak was found at 1.8 times the void volume. Addition of nonspecific IgG did not alter this binding peak. Addition of monospecific anti-hepatic ligandin IgG virtually obliterated binding by this fraction. The major portion $(90 \%)$ of the organic anion binding in the peak, occurring at 1.8 times the void volume, was therefore attributed to a renal protein precipitated by antiserum against hepatic ligandin.

Studies were performed to determine whether organic anions bound to the third protein-binding peak in vitro were similarly bound when injected in vivo. The elution patterns obtained from supernates of $25 \%$ homogenates prepared from kidneys removed $5 \mathrm{~min}$ after i.v. injection of BSP, BSP-GSH, phlorizin, probenecid, conjugated bilirubin, $\mathrm{PAH}$, or penicillin revealed elution patterns similar to those seen when these anions were added in vitro. The ligandin-containing peak contained 52-89\%; the second (albumin-containing) peak contained $11-31 \%$ and the first peak contained $2-12 \%$ of each protein-bound organic anion.

The binding protein in renal supernate was purified as follows. Immunoreactive protein was eluted from

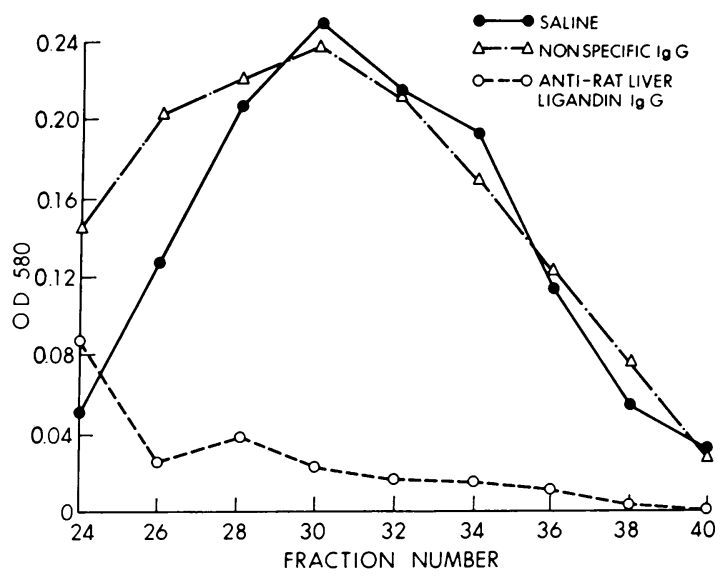

FIGURE 2 The effect of anti-rat liver ligandin IgG and nonspecific IgG on BSP binding by $Y$ fraction from supernate of rat kidney homogenate. The $\mathrm{Y}$ supernatant fraction from a $25 \%$ homogenate of $2 \mathrm{~g}$ rat kidney was divided into three equal portions, to which were added $5 \mathrm{ml}$ saline, control IgG, or anti-rat liver ligandin IgG. After incubation, centrifugation, and removal of immune precipitates, $5 \mathrm{mg}$ of BSP was added to each portion and chromatography was performed on Sephadex G-100.

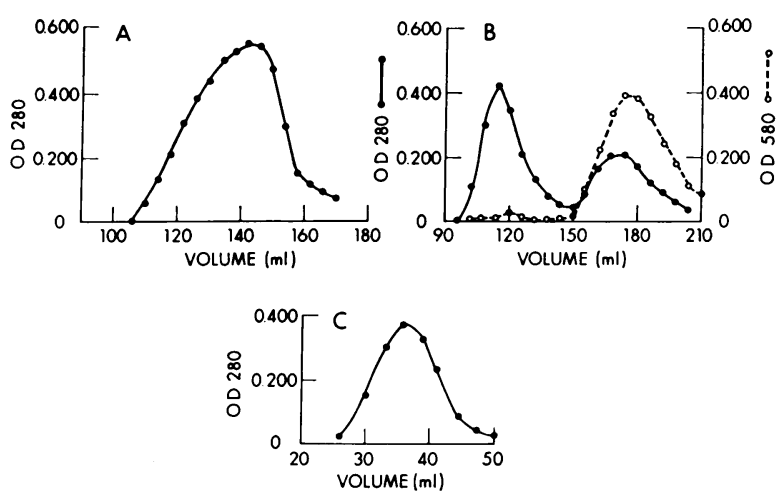

Figure 3 Purification of ligandin from supernate of rat kidney homogenate. (A) Elution of void volume peak containing ligandin from TEAE with $0.01 \mathrm{M}$ Tris, $\mathrm{pH}$ 8.8. (B) Subsequent chromatography on Sephadex G-100 with added BSP in $0.01 \mathrm{M}$ phosphate buffer, $\mathrm{pH}$ 7.4. (C) Purification of BSP-binding peak on QAE Sephadex in 0.01 $\mathrm{M}$ Tris, $\mathrm{pH}$ 8.8. See Methods and Results for further details.

TEAE in a single peak immediately after the void volume (Fig. 3). After concentration, addition of BSP, and G-100 Sephadex chromatography, immunoreactive protein was eluted in the second peak at 1:8 times the void volume. BSP binding was almost entirely limited to this peak, in which immunodiffusion revealed the presence of a protein that reacts with anti-ligandin IgG. QAE-A50 chromatography resulted in a single peak that contained binding protein, as determined by BSP binding on Sephadex G-100 chromatography. Purity of the protein isolated by QAE-A50 chromatography was demonstrated by finding a single protein band on isoelectric focusing (Fig. 4) and SDS gel electrophoresis in the presence or absence of $\beta$-mercaptoethanol (Fig. 5). By comparative gel filtration and acrylamide gel electrophoresis, both hepatic ligandin and the renal protein have a mol wt of approximately 44,000 and exist as dimers. With addition of $\beta$-mercaptoethanol, mol wt 22,000 monomers are found. The isoelectric point of both renal and hepatic proteins is $\mathrm{pH}$ 8.9. Amino acid analysis revealed similar composition (Table II). As determined by quantitative radial immunodiffusion, approximately $10 \%$ of the $300 \mathrm{mg}$ of renal organic anion-binding protein present in the original supernate was recovered as pure protein.

Antibody produced against the renal organic anionbinding protein was monospecific on immunoelectrophoresis (Fig. 6) and immunodiffusion revealed immunologic identity between the renal protein, hepatic ligandin, and a protein present in the supernate of liver, kidney, and gut homogenates, but not in serum (Fig. 7). Immunodiffusion precipitation reaction of anti-renal organic anion-binding protein with kidney and liver supernates was blocked by prior incubation with mono- 


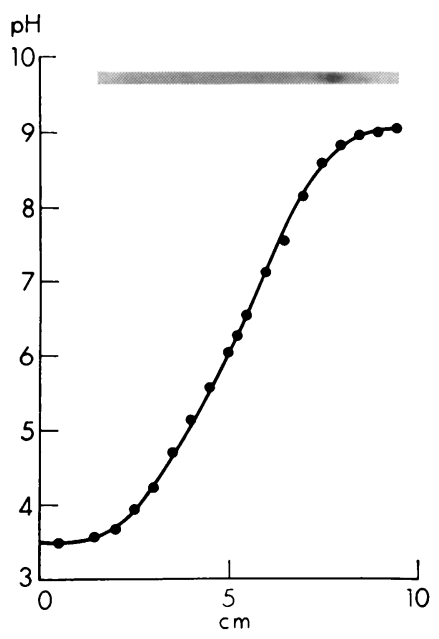

FIGURE 4 Isoelectric focusing of purified rat kidney ligandin on $6 \%$ polyacrylamide gel. Gels containing $6 \%$ (wt/ vol) polyacrylamide, $2 \%$ (wt/vol) ampholyte, $0.02 \%$ (vol/ $\mathrm{vol}$ ) TEMED, and $0.002 \%$ (vol/vol) ammonium persulfate were prepared in $3-\mathrm{mm}$ tubes. Electrolytes were $0.01 \mathrm{M}$ phosphoric acid and $0.02 \mathrm{M}$ sodium hydroxide. Gels were run for $30 \mathrm{~min}$ at $1 \mathrm{~mA} / \mathrm{gel}$ to remove ammonium persulfulate and create a partial $\mathrm{pH}$ gradient before $10-50 \mu \mathrm{g}$ of renal ligandin in 10-50 $\mu \mathrm{l}$ was applied. Electrofocusing was performed for $3-4 \mathrm{~h}$ at $1 \mathrm{ml} / \mathrm{gel}$. Gels were stained for $1 \mathrm{~h}$ in $0.2 \%$ fast green in $40 \%$ ethanol, $10 \%$ acetic acid, and $50 \%$ water, and destained in $10 \%$ ethanol, $10 \%$ acetic acid, and $80 \%$ water. The $\mathrm{pH}$ gradient was measured in eluates of gel sections. Gels were sliced with a razor blade into $0.50-\mathrm{cm}$ segments and shaken with $1.0 \mathrm{ml}$ water for $1 \mathrm{~h}$ before the $\mathrm{pH}$ was measured at a constant temperature.

specific antibody prepared against liver ligandin (Fig. $8)$. Prior incubation of liver supernate with anti-renal organic anion-binding protein also abolished immunoelectrophoresis reactions between renal supernate and anti-kidney ligandin (Fig. 6).

Circular dichroism analysis of the renal protein revealed ellipticity minima at 222 and $208 \mathrm{~nm}$, as well as in the peptide absorption region. The molar ellipticity of liver ligandin and the renal protein at $222 \mathrm{~nm}$ were similar, indicating that both proteins have very similar overall conformations. Both proteins exhibited approximately $40 \%$ helical structure (19). In the presence of bilirubin, the circular dichroism spectrum revealed three new ellipticity extrema at $405 \mathrm{~nm}, 455 \mathrm{~nm}$, and $515 \mathrm{~nm}$ (Fig. 9). The $405 \mathrm{~nm}$ band increased in magnitude up to a bilirubin protein molar ratio $1: 1$. The $455 \mathrm{~nm}$ band reached $65 \%$ saturation after addition of $1 \mathrm{~mol}$ of bilirubin and leveled off at a molar ratio between 2 and 3 . In contrast, the $515 \mathrm{~nm}$ band increased after addition of 2 or more mol of bilirubin. The ellipticity pattern and titration curves at these wavelengths are virtually identical to those obtained with liver ligandin (19). Addition of increasing amounts of BSP to a solution of the renal protein and bilirubin (molar ratio $1: 1$ ) decreased the magnitude of all three ellipticity bands (Fig. 10). From these inhibitory effects, the association constant of $\mathrm{BSP}$ to renal ligandin was calculated to be $10^{8} \mathrm{M}^{-1}$. which is also the association constant of BSP binding to hepatic ligandin (19). PAH, probenecid, and penicillin caused less marked decrease in ellipticity produced by bilirubin and ligandin, with an affinity constant of $10^{3} \mathrm{M}^{-1}$.

The results of binding studies in vivo and in vitro, and physical-chemical, immunological, structural, and binding site investigations indicate that the renal protein is probably identical to hepatic ligandin and will, therefore, be referred to as renal ligandin.

By quantitative radial immunodiffusion, the concentration of hepatic ligandin was $39.5 \pm 2.3 \mu \mathrm{g} / \mathrm{mg}$ supernatant protein (mean $\pm S E M$ ). Treatment with phenobarbital DDT, PCN, or TCDD increased the concentration to $76.4 \pm 4.3(P<0.001), 80.5 \pm 2.7(P<0.001)$, $78.6 \pm 3.1$, and $83.1 \pm 3.2 \mu \mathrm{g} / \mathrm{mg}$ protein $(P<0.001$, respectively). The concentration of renal ligandin in control rats was $31.2 \pm 2.2 \mu \mathrm{g} / \mathrm{mg}$ protein. In TCDD-treated rats, renal ligandin concentration was increased to 49.6 $\pm 2.6 \mu \mathrm{g} / \mathrm{mg}$ protein $(P<0.001)$ and total kidney weight was not significantly increased $(P>0.5)$. In contrast to hepatic ligandin, renal ligandin levels were not significantly higher in animals receiving phenobarbital $(29.0 \pm 3.9, \quad P>0.5)$, DDT $(27.9 \pm 1.8, \quad P>$

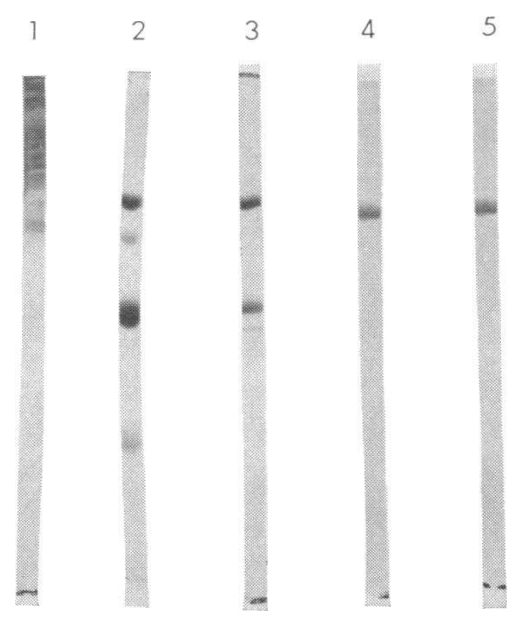

Figure 5 Polyacrylamide gel electrophoresis in $0.1 \%$ SDS. Protein samples of $100-150 \mu \mathrm{g}$, treated with $1 \%$ SDS and $1 \% \beta$-mercaptoethanol in $0.01 \mathrm{M}$ phosphate buffer and heated to $100^{\circ} \mathrm{C}$ for $1 \mathrm{~min}$, were applied to $10 \%$ acrylamide, $0.1 \%$ SDS gel, $10 \mathrm{~cm}$ in length and run at $10 \mathrm{~mA} / \mathrm{gel}$ from cathode (top) to anode (bottom) for $3.5 \mathrm{~h}$. After fixing in $10 \%$ trichloracetic acid, gels were stained with Coomassie blue. Samples from left to right are rat liver supernate $(100,000 \mathrm{~g})$, and ligandin-containing peaks after TEAE (2), Sephadex G-100 (3) and QAE (4) chromatography. Homogeneous hepatic ligandin $(5)$ is included for comparison.

1014 R. Kirsch, G. Fleischner, K. Kamisaka, and I. M. Arias 


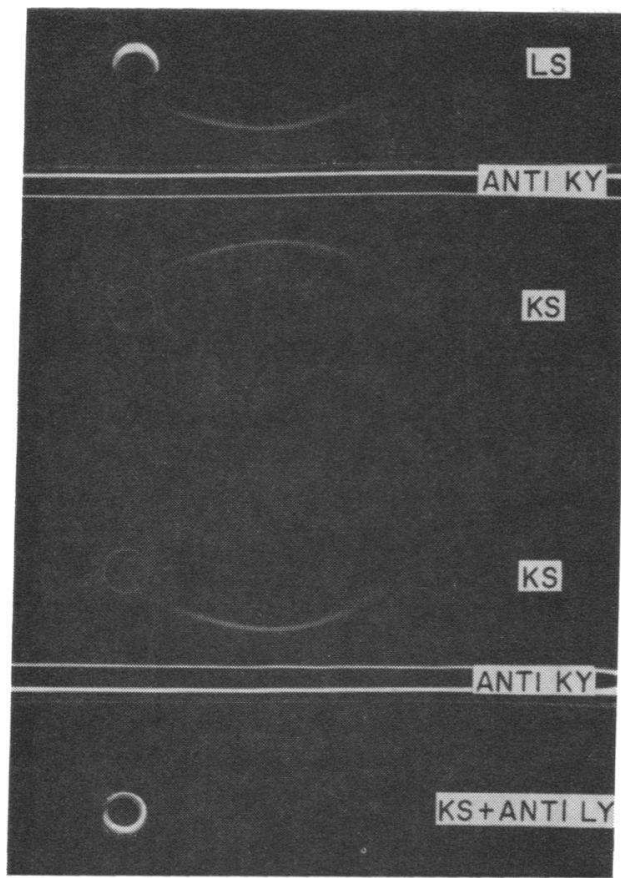

FIGURE 6 Immunoelectrophoresis of rat kidney supernate fraction (KS) and anti-rat kidney ligandin serum (anti $\mathrm{KY}$ ) before and after absorption with anti-rat liver ligandin IgG (anti LY).

$0.5)$, or $\mathrm{PCN}(29.6 \pm 2.3 \mu \mathrm{g} / \mathrm{mg}$ protein, $P>0.5)$. Both renal and hepatic ligandin concentrations were unaffected by daily i.p. administration of corn oil for 14 days $(P>0.05)$ or by single i.p. administration of $p$-dioxane-corn oil 7 days before study $(P>0.05)$ (Table III). Renal ligandin at birth was less than 2 $\mu \mathrm{g} / \mathrm{mg}$ protein. Accurate quantitation at this level was not possible.

To study the function of renal ligandin, a competitive study in vivo was performed (Table III, Fig. 11).

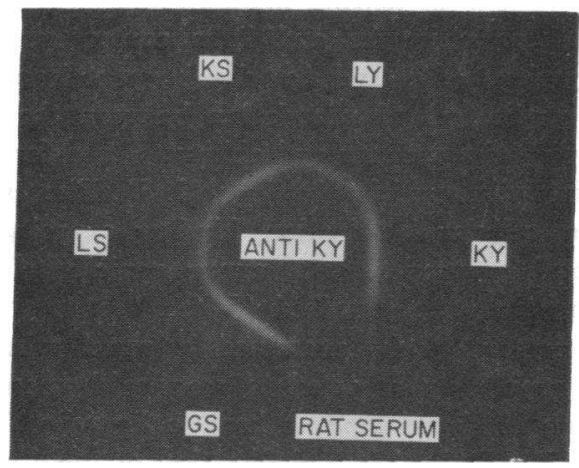

FIGURE 7 Immunodiffusion precipitation between anti-rat kidney ligandin serum (anti KY) and liver ligandin (LY), kidney ligandin (KY), rat serum, and supernate from rat kidney, liver, and small intestinal mucosal homogenates (KS, LS, and GS, respectively).

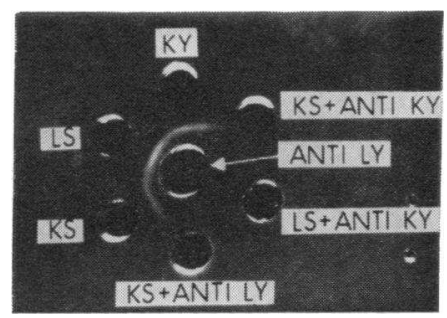

FIgURE 8 Effect of absorption of anti-rat kidney ligandin serum (anti KY) and anti-rat liver ligandin IgG (anti LY) on immunodiffusion precipitation reactions with kidney and liver supernate (KS and LS).

Reduced ratio of renal to plasma penicillin occurred when either BSP or probenecid was simultaneously administered instead of saline (Table III). Mean plasma penicillin radioactivity at $5 \mathrm{~min}$ was higher when BSP or probenecid were administered. The relative amount of radioactivity eluted from G-100 Sephadex columns in the ligandin fraction is shown in Table III. When probenecid or BSP were injected, the relative amount of radioactivity bound to ligandin fraction was significantly reduced, unassociated with any change in percentage of radioactivity in the void volume. The proportion of total protein-bound ligand bound to albumin increased. When renal-to-plasma radioactivity ratios were plotted against the percent of

TABLE II

Amino Acid Analysis

\begin{tabular}{lrr}
\hline & \multicolumn{2}{c}{ Ligandin isolated from } \\
\cline { 2 - 3 } & Kidney & Liver \\
\hline & \multicolumn{2}{c}{ residues $/$ mol } \\
Lysine & 33 & 34 \\
Histidine & 5 & 5 \\
Arginine & 20 & 21 \\
Aspartic acid & 36 & 36 \\
Threonine & 13 & 12 \\
Serine & 16 & 15 \\
Glutamic acid & 42 & 42 \\
Proline & 19 & 19 \\
Glycine & 19 & 19 \\
Alanine & 26 & 28 \\
Half-cystine & 4 & 4 \\
Valine & 18 & 16 \\
Methionine & 15 & 15 \\
Isoleucine & 18 & 18 \\
Leucine & 47 & 46 \\
Tyrosine & 14 & 15 \\
Phenylalanine & 17 & 17 \\
Tryptophane & 7 & 7 \\
\hline
\end{tabular}

Mean amino acid analysis were performed in duplicate after hydrolysis of $100 \mathrm{mg}$ ligandin purified from rat kidney and liver in $6 \mathrm{~N} \mathrm{HCl}$ for $16 \mathrm{~h}$ at $110^{\circ} \mathrm{C}$. 


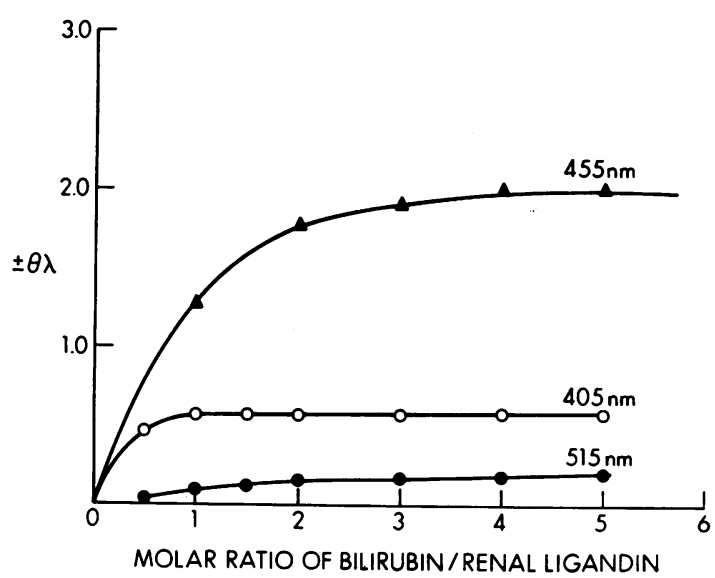

Figure 9 Circular dichroism analysis (molar ellipticity) of renal ligandin and bilirubin at molar ratios of 1-5. Renal organic anion binding protein was $10-5 \mathrm{M}$ in $0.01 \mathrm{M}$ phosphate buffer, $\mathrm{pH}$ 7.4. Bilirubin solution was freshly prepared in dilute $\mathrm{NaOH}$ at various concentrations before examination in a Cary Model 60 spectropolarimeter. See Methods for further details.

protein-bound radioactivity bound to ligandin, a regression coefficient of $-0.80(P<0.001)$ was obtained.

Treatment of rats with TCDD resulted in an increased renal/plasma $\left[{ }^{10} \mathrm{C}\right]$ penicillin ratio, increased renal excretion of $\left[{ }^{[4} \mathrm{C}\right]$ penicillin into the urinary bladder 5 min after i.v. injection, and a significantly greater proportion of $\left[{ }^{\mathrm{IA}} \mathrm{C}\right]$ penicillin bound to the ligandin-containing peak (Table III).

\section{DISCUSSION}

Ligandin ( $\mathrm{Y}$ protein) is the major organic anionbinding protein in liver and is considered important in

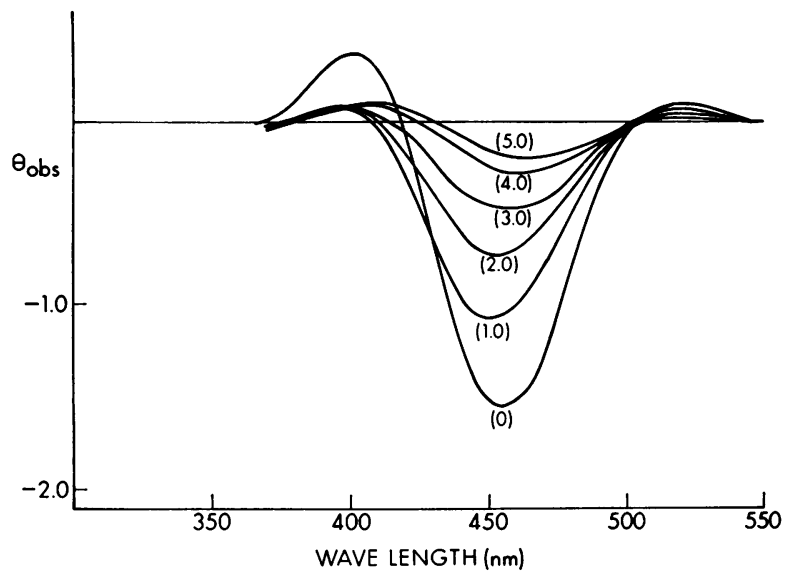

FIgURe 10 Effect of BSP (0-5 M) on molar ellipticity of bilirubin and renal ligandin (1:1 molar ratio). BSP was prepared in distilled water at various concentrations and mixed with a 1:1 molar combination of renal organic anionbinding protein and bilirubin. Molar ellipticity was recorded as described under Methods.

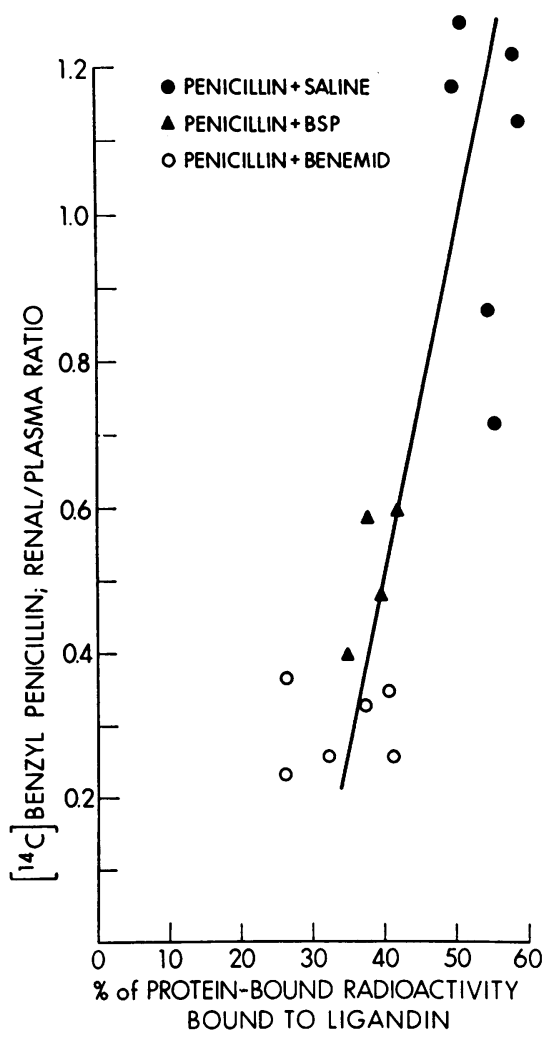

Figure 11 Renal plasma ratio of $\left[{ }^{14} \mathrm{C}\right]$ benzyl penicillin and percentage of protein-bound radioactivity bound to renal ligandin in rats $5 \mathrm{~min}$ after intravenous injection of penicillin and saline, BSP, or probenecid. Further details are described under Methods and appear in Table III. $y=20.5 x$ $+29.4 ; r=0.8006 ; P<0.001$.

net hepatic uptake of organic anions for several reasons: (a) Many organic anions, including drugs, dyes, cholecystographic agents, etc., when given in vivo or added in vitro to liver supernate, are bound to ligandin (1). (b) Phenobarbitol and other drugs and chemicals induce synthesis of hepatic ligandin and simultaneously enhance hepatic uptake and liver content of various organic anions (4). And (c) developmental and phylogenetic studies reveal correlation between the appearance of ligandin in liver and ability to transfer organic anions from plasma into the liver $(2,3)$. The tissue distribution, cellular localization, binding capacity, physicochemical properties, and immunogenicity of hepatic ligandin have been described (5-7).

The present study examined a renal tubular cell protein previously reported to react with monospecific antiserum produced against hepatic ligandin. The elution profile obtained by gel filtration of renal supernate and various organic anions was similar to that found with hepatic supernate, and the elution ratio of the major organic anion-binding peak of renal supernate was identical with either hepatic $\mathrm{Y}$ fraction or purified 
TABLE III

The Effect of Probenecid, BSP, TCDD, and DDT on Tissue Distribution and Renal Uptake and Binding of $\left[{ }^{14} \mathrm{C}\right]$ Benzyl Penicillin to Ligandin

\begin{tabular}{|c|c|c|c|c|c|c|c|}
\hline & No. & $\begin{array}{c}\text { Total } \\
\text { plasma } \\
\text { radio- } \\
\text { activity }\end{array}$ & $\begin{array}{c}\text { Total } \\
\text { kidney } \\
\text { radio- } \\
\text { activity }\end{array}$ & $\begin{array}{l}\text { Kidney/ } \\
\text { plasma } \\
\text { PCN } \\
\text { radio- } \\
\text { activity }\end{array}$ & $\begin{array}{c}\text { Ratio- } \\
\text { activity } \\
\text { in urinary } \\
\text { bladder }\end{array}$ & $\begin{array}{l}\text { Total } \\
\text { liver } \\
\text { radio- } \\
\text { activity }\end{array}$ & $\begin{array}{l}\% \text { of total } \\
\text { protein- } \\
\text { bound } \\
\text { radio- } \\
\text { activity } \\
\text { bound } \\
\text { to renal } \\
\text { ligandin }\end{array}$ \\
\hline & & $\%$ dose & \% dose & & $\%$ dose & \% dose & \\
\hline \multicolumn{8}{|l|}{ Control rats } \\
\hline Penicillin + saline & 5 & $19.7 \pm 1.5$ & $21.9 \pm 1.8$ & 1.29 & $10.1 \pm 1.4$ & $31.3 \pm 3.2$ & $53 \pm 1.4$ \\
\hline Penicillin + probenecid & 4 & $31.6 \pm 1.0 \ddagger$ & $9.1 \pm 0.8 \ddagger$ & $0.29 \ddagger$ & $4.3 \pm 1.2 \ddagger$ & $27.6 \pm 2.4$ & $35 \pm 2.7 \ddagger$ \\
\hline Penicillin + BSP & 4 & $25.3 \pm 0.8 \ddagger$ & $12.3 \pm 0.5 \ddagger$ & $0.49 \ddagger$ & $6.1 \pm 1.4 \ddagger$ & $23.4 \pm 1.8 \ddagger$ & $39 \pm 1.5 \ddagger$ \\
\hline \multicolumn{8}{|l|}{ Chemical drug-treated rats } \\
\hline TCDD; Penicillin + saline & 4 & $10 \pm 0.6 \ddagger$ & $31.6 \pm 1.3 \ddagger$ & $3.16 \ddagger$ & $19.6 \pm 1.1 \ddagger$ & $42.6 \pm 3.8$ & $78 \pm 3.1 \ddagger$ \\
\hline DDT, penicillin + saline & 4 & $12.6 \pm 0.5^{*}$ & $23.1 \pm 1.6$ & $1.83^{*}$ & $9.3 \pm 1.8$ & $39.6 \pm 1.2^{*}$ & $56 \pm 2.9$ \\
\hline Corn oil, penicillin + saline & 2 & $18.7,21.2$ & $23.4,19.6$ & 1.07 & $9.2,8.7$ & $30.6,32.4$ & 49,52 \\
\hline$p$-Dioxan, corn oil, penicillin + saline & 2 & $19.2,19.8$ & $20.6,22.4$ & 1.07 & $10.3,9.1$ & $29.2,29.4$ & 57,48 \\
\hline
\end{tabular}

Results are expressed as means \pm SEM $\left[{ }^{14} \mathrm{C}\right]$ Benzyl penicillin $\left(10 \mathrm{mg}, 10^{7} \mathrm{dpm}\right)$ was injected i.v. in normal saline or in combination with probenecid $(50 \mathrm{mg})$, or BSP $(25 \mathrm{mg})$. Radioactivity was measured in plasma, kidney, liver, and urinary bladder $5 \mathrm{~min}$ later. Binding to ligandin was determined by chromatography of renal 100,000 $\mathrm{g}$ supernate on Sephadex G-100. Rats received daily i.p. injections of DDT for 14 days or a single i.p. injection of TCDD in p-dioxane, corn oil $(2 \mathrm{ml} / \mathrm{kg}) 7 \mathrm{days} \mathrm{before} \mathrm{study.}$ Additional groups of rats received either a single i.p. injection of $p$-dioxane in corn oil $(2 \mathrm{ml} / \mathrm{kg}) 7$ days before study or daily i.p. injections of corn oil for 14 days before study. In comparison with controls, ${ }^{*} P<0.01$ and $\ddagger P<0.005$.

ligandin. The renal organic anion binding fraction largely disappeared after incubation with antibody against hepatic ligandin, but not with control IgG, suggesting that the renal protein is immunologically identical to ligandin. By the technique developed for purification of hepatic ligandin, the renal protein was purified and has identical physicochemical properties to hepatic ligandin. Similarities between the hepatic and renal organic anion-binding proteins include electrophorectic mobility, molecular weight, isoelectric point, amino acid analysis, helical content, and organic anionbinding specificity and affinity. Antiserum was raised against renal organic anion-binding protein and blocking experiments established immunological identity of the hepatic and renal proteins. The above evidence is felt sufficient to permit designation of the protein as renal ligandin.

Studies relating renal ligandin to organic anion transport were restricted by lack of a mutant strain exhibiting a defect in renal organic anion uptake as well as absence of techniques allowing direct intracellular measurements of ligand and ligandin. These restrictions limit functional studies to correlating organic anion transport with ligandin concentration. Synthesis of ligandin in the kidney, in contrast with hepatic ligandin, was not induced by phenobarbital, DDT, or PCN. However, treatment with TCDD almost doubled the concentration of renal as well as hepatic ligandin. Immunofluorescence studies in two rats utilizing rhodamine conjugated anti-ligandin IgG suggest that ligandin is localized to the proximal convoluted tubules in TCDD-treated rats, as it is in control rats (unpublished observations). The apparent failure of phenobarbital, DDT, or PCN to alter the concentration of renal ligandin may result from inability of these drugs to enter and bind within the proximal tubular cells, or may reflect different control of renal ligandin when compared with hepatic ligandin. The findings of reduced renal ligandin levels in rats less than $6 \mathrm{~h}$ olds, when renal tubular organic anion transport is reduced, resembles results of ontogenetic studies of liver ligandin in rat, monkey, and man (2).

Additional evidence consistent with the hypothesis that renal ligandin plays a role in organic anion transport by the kidney was obtained by the competitive study in vivo. Probenecid, BSP, and penicillin are bound by ligandin. If binding to ligandin is related to organic anion uptake, administration of an anion that competes for binding should diminish uptake of organic anions having less affinity for the protein. For example, BSP competes with other organic anions for binding to hepatic ligandin, and injection of BSP before administration of various other organic anions diminished the amount of these anions bound to ligandin 
as well as their hepatic uptake. In the present study, competition between penicillin and BSP or probenecid for binding to ligandin was associated with diminished renal uptake of penicillin. The mechanism whereby probenecid reduces renal excretion of penicillin is unclear (23). The present findings suggest that competition for binding to ligandin may explain the pharmacologic action of probenecid.

Simultaneous administration of $\mathrm{BSP}$ or probenecid with $\left[{ }^{14} \mathrm{C}\right]$ penicillin increased the plasma/renal ratio of radioactivity $5 \mathrm{~min}$ after administration of the organic anions, as well as excretion of $\left[{ }^{14} \mathrm{C}\right]$ penicillin in the urinary bladder. Hepatic content of $\left[{ }^{14} \mathrm{C}\right]$ penicillin was significantly reduced, suggesting that BSP and probenecid reduced renal as well as hepatic net transfer of $\left[{ }^{14} \mathrm{C}\right]$ penicillin from plasma. These changes in vivo are paralleled by competitive binding of BSP or probenecid to ligandin with respect to $\left[{ }^{14} \mathrm{C}\right]$ penicillin, as determined in vitro and by circular dichroism studies with homogenous renal and hepatic ligandin (19).

At present, there is no definitive way to quantitate organic anion binding to ligandin intracellularly. We cannot exclude the possibility that organic anion binding by supernatant fractionation after gel-filtration after administration of the anion in vivo is influenced by disruption of cells and organelles and release of organic anions from sites other than ligandin. Evidence against this interpretation includes the results of binding studies to ligandin in vitro, cellular localization and abundance of ligandin, reciprocal relationship between competitive binding to ligandin in vitro and competitive studies in vivo, and correlation of effects of DDT and TCDD on renal ligandin with measures of renal organic anion transport in vivo. TCDD may affect components of the renal organic transport system other than ligandin; however, limited knowledge of the molecular aspects of this system does not permit direct experimental study at this time. TCDD administration increases hepatic microsomal oxygenase and ALA synthetase activities (24), and hepatic necrosis is observed in rats after administration of doses greatly in excess of those used in the current study.

Passive binding of organic anions by ligandin in the renal proximal tubular cell should not increase their net transfer from plasma to urine unless their intracellular concentration directly affects the rate of transport from the cell to the tubular lumen, or unless ligandin is a component of the transport process, presumably in the plasma membrane of the tubular cell. Based primarily on studies using kidney slices, it is believed that the renal organic anion active transport system is located between plasma and tubular cell, and that passive diffusion and reabsorption occur across the tubular cell-lumenal surface (25). Thus far, with immunofluorescence techniques, ligandin has not been localized to plasma membrane fractions of liver or kidney (unpublished observations). For these reasons, we may only postulate that ligandin is a component in the organic anion translocation system in the proximal tubular cell and regulates the net flux of organic anions into this cell. In TCDD-treated rats, renal plasma $\left[{ }^{14}\right]$ penicillin was significantly increased, as was binding of $\left[{ }^{14} \mathrm{C}\right]$ penicillin to renal ligandin and recovery of $\left[{ }^{14} \mathrm{C}\right]$ penicillin in the urinary bladder.

Hepatic ligandin purified to homogeneity binds GSH and is identical with GSH transferase B (26), one of five homogenous GSH transferases from rat liver (27). Renal ligandin also binds GSH and exhibits GSH transferase $B$ activity with chlorodinitrobenzene and ethacrynic acid as substrates $(26,28)$. These observations suggest that renal and hepatic ligandin may also function in GSH storage and/or metabolism.

\section{ACKNOWLEDGMENTS}

TCDD was provided by Dr. Alan Poland, University of Rochester School of Medicine, Rochester, N. Y., and PCN was provided by Professor Hans Selye, University of Montreal School of Medicine, Montreal, Canada.

This work was supported by grants from the U. S. Public Health Service (AM 16281, 02019, 05384, and 17702) and the New York Heart Association and Heart Fund.

\section{REFERENCES}

1. Levi, A. J., Z. Gatmaitan, and I. M. Arias. 1969. Two hepatic cytoplasmic protein fractions, $Y$ and $Z$, and their possible role in the hepatic uptake of bilirubin, sulfobromophthalein, and other anions. J. Clin. Invest. 48: 2156-2167.

2. Levi, A. J., Z. Gatmaitan, and I. M. Arias. 1970. Deficiency of hepatic organic anion-binding protein, impaired organic anion uptake by liver and "physiologic" jaundice in newborn monkeys. N. Engl. J. Med. 283: 1136-1139.

3. Levine, R. J., H. Reyes, A. J. Levi, Z. Gatmaitan, and I. M. Arias. 1971. Phylogenetic study of organic anion transfer from plasma into the liver. Nat. New Biol. 231 : 277-279.

4. Reyes, H., A. J. Levi, Z. Gatmaitan, and I. M. Arias. 1971. Studies of $Y$ and $Z$, two hepatic cytoplasmic organic anion-binding proteins: effect of drugs, chemicals, hormones, and cholestasis. J. Clin. Invest. 50: 22422252.

5. Litwack, G., B. Ketterer, and I. M. Arias. 1971. Ligandin: A hepatic protein which binds steroids, bilirubin, carcinogens, and a number of exogenous organic anions. Nature (Lond.). 234: 466-467.

6. Fleischner, G., J. Robbins, and I. M. Arias. 1972. Immunologic studies of $\mathrm{Y}$ protein. A major cytoplasmic organic anion-binding protein in rat liver. J. Clin. Invest. $51: 677-684$.

7. Fleischner, G., S. Mishkin, H. Reyes, J. Robbins, A. J. Levi, Z. Gatmaitan, and I. M. Arias. 1971. On the structure and function of $\mathrm{Y}$ protein. J. Clin. Invest. 50: 31a. (Abstr.) 
8. Ostrow, J. D., and N. H. Murphy. 1970. Isolation and properties of conjugated bilirubin from bile. Biochem. $J$. 120: 311-327.

9. Whelan, G., J. Hoch, and B. Combs. 1970. A direct assessment of the importance of conjugation for biliary transport of sulfobromophthalein sodium. J. Lab. Clin. Med. 75: 542-557.

10. Friedman, S. M., J. R. Polley, and C. L. Friedman. 1947. The clearance of insulin and sodium $p$-aminohippurate in the rat. Am. J. Physiol. 150: 340-352.

11. Wang, L. 1959. Plasma volume, cell volume, total blood volume and $F$ cells factor in the normal and splenectomized Sherman rat. Am. J. Physiol. 196: 188192.

12. Ouchterlony, Ö. 1958. Diffusion-in-gel methods for immunological analysis. Prog. Allergy. 5: 1-78.

13. Righetti, P., and J. W. Drysdale. 1971. Isoelectric focusing in polyacrylamide gels. Biochem. Biophys. Acta. 236: 17-28.

14. Maizel, J. V., K. Harber, and N. P. Salzman. 1969. Fundamental Techniques in Virology. Academic Press, Inc., New York. 334.

15. Graber, P. 1959. Immunoelectrophoretic analysis. Methods Biochem. Anal. $7:$ 1-38.

16. Mancini, G., O. Carbonara, and J. F. Heremans. 1965. Immunochemical quantitation of antigens by single radial immunodiffusion. Immunochemistry. 2: 235-254.

17. Lowry, O. H., N. J. Rosebrough, A. L. Farr, and R. J. Randall. 1951. Protein measurements with the Folin phenol reagent. J. Biol. Chem. 193: 265-275.

18. Blauer, G., and T. E. King. 1970. Interactions of bilirubin with bovine serum albumin in aqueous solution. J. Biol. Chem. 245 : 372-381.

19. Kamisaka, K., I. Listowsky, and I. M. Arias. 1973 Circular dichroism studies of $\mathrm{Y}$ protein (ligandin), a major organic anion binding protein in liver, kidney, and small intestine. Ann. N. Y. Acad. Sci. 226: 148153.

20. Kamisaka, K., I. Listowsky, J. J. Betheil, and I. M. Arias. 1974. Competitive binding of bilirubin, sulfobromophthalein, indocyanine green, and other organic anions to human and bovine serum albumin. Biochem. Biophys. Acta. 365: 169-180.

21. Greenfield, N., and G. D. Fasman. 1969. Computed circular dichroism spectra for the evaluation of protein conformation. Biochemistry. 8: 4108-4116.

22. Chen, Y-H., J. T. Yang, and H. M. Martinez. 1972. Determination of the secondary structures of proteins by circular dichronism and optical rotatory dispersion. Biochemistry. 11 : 4120-4131.

23. Weiner, I. M., J. A. Washington, II, and G. H. Mudge. 1960. On the mechanism of action of probenecid on renal tubular secretion. Bull. Johns Hopkins Hosp. 106: 333-346.

24. Poland, A., and E. Glover. 1974. Comparison of 2,3,7,8tetrachlorodibenzo- $p$-dioxin, a potent inducer of aryl hydrocarbon hydroxylase, with 3-methylcholanthrene. Mol. Pharmacol. 10: 349-359.

25. Bárány, E. H. 1973. The liver-like anion transport system in rabbit kidney, uvea, and choroid plexus. II. Efficiency of acidic drugs and other anions as inhibitors. Acta Physiol. Scand. 88: 491-504.

26. Habig, W., M. Pabst, G. Fleischner, Z. Gatmaitan, I. M. Arias, and W. Jakoby. 1974. The identity of glutathione transferase $\mathrm{B}$ and ligandin, the major organic anion binding protein of liver. Proc. Natl. Acad. Sci. 71 : 3879-3882.

27. Fleischner, G., Z. Gatmaitan, K. Kamisaka, W. Habig, W. Jakoby, and I. M. Arias. 1975. Ligandin ( $Y$ protein) and glutathione (GSH) metabolism. Gastroenterology. In press.

28. Pabst, M. J., W. H. Habig, and W. B. Jakoby. 1973. Mercapturic acid formation: the several glutathione transferases of rat liver. Biochem. Biophys. Res. Commun. 52: 1123-1128.

29. Fleischner, G., R. Kirsch, K. Kamisaka, I., Listowsky, Z. Gatmaitan, W. Habig, M. Pabst, W. Jakoby, and I. M. Arias. 1974. Identity of ligandin ( $Y$ protein) and glutathione transferase $B$ : its role in ethacrynic acid metabolism and organic anion transport in kidney and liver. Gastroenterology. $67: 792$. 